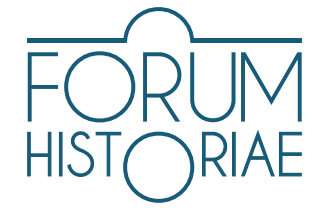

\title{
Hungarian POWs in Italy and Their Future Prospects After WWI
}

\author{
Balázs Juhász
}

\begin{abstract}
JUHÁSZ, Balázs. Hungarian POWs in Italy and Their Future Prospects After WWI.

For many Hungarian soldiers in Italy, 3 and 4 November 1918 meant not the armistice and a return home, but the beginning of a prolonged stay in one of the Italian prison camps. It is widely known why these soldiers fell into captivity, but their prospects of returning home are still somewhat unclear. The topic is particularly interesting since some of the Hungarian soldiers were to return to a different country from the one they left given that from 1918-1919 onward, their native land now belonged to one of the successor states of the Austro-Hungarian Monarchy. The issue of ethnicity was entwined with various political and ideological concerns in regard to which ethnic groups returned home first and for what reasons. In fact, there were some attempts made by Hungarian counter-revolutionary groups in Vienna, Arad and later in Szeged, to demand the release of Hungarian POWs so they could be enlisted in a war against the Hungarian Republic of Councils. The situation in Italy should not be overlooked as well, given that prisoners were generally an important labour force for them. We must mention also the Paris Peace Conference which addressed the future of these POWs. In view of the abovementioned, the topic cannot be viewed only from the Italian or Hungarian perspective. This study deals with the various aspects of Hungarian POWs' returning home after the Armistice of Villa Giusti.
\end{abstract}

Keywords: Italy, Hungary, POWs, escape, bolshevism, intervention, WWI

DOI: https://doi.org/10.31577/forhist.2021.15.1.6

$\mathrm{I}$ n November 1918, after the end of the First World War, several hundred thousand prisoners of war were waiting in Italy to return to their home countries. Most came from the territory of the former Austro-Hungarian Monarchy, which had been dissolved during their absence. Many became prisoners on the last day of the war due to some discrepancies in the interpretation of the armistice, and a large amount did not realize that their status as prisoners of war may cause their return home to be delayed for up to one and half years. During this time, the hinterland was undergoing continuous change. The successor countries of the monarchy fought for territories and resources, a fact that had become obvious not only for the participants of the Paris Peace Conference, but also for the various affected populaces given that several armed incidents - even a prolonged war in Hungary - caused unrest in the civil sphere. The situation was further aggravated by the spread of Bolshevik ideology towards the West, which resulted in the establishment of a few Republics of Councils in several Central European countries. Of these, the Hungarian Republic of Councils is special, among other reasons, because ideological tensions were mixed with a fundamentally nationalist war fought for territorial integrity.

The POWs had access to assorted press reports and therefore had the opportunity to follow events in their home countries. Of course this led to many prisoners moving to take action as the hopelessness they faced in captivity was further aggravated by an 
uncertainty surrounding the fate of their relatives at home. It is not possible to characterize all the opinions of prisoners as no survey was taken at the end of the war and the scarcity of preserved documents does not allow for research in this domain. There are, however, enough resources that allow for the sketching of some trends. These are interesting not only because they show the behaviour model of a well-defined group in a crisis situation created by wartime captivity, but also because large-scale politics and diplomacy attempted to exploit their endeavors. Thus, impetus coming from the bottom and from the top met at certain points. In this context, this study examines the opportunities for repatriation of the Hungarian prisoners of war and also presents the reactions of large-scale politics to the requests made by prisoners of war to return home. ${ }^{1}$

Sergeant Leonhard Scuber, Sergeant Bernát Lindner, Sergeant Jozef Singer, Commander Pál Rőhling and Ensign Mihály László wrote a farewell letter before they fled the Italian labour corps in late May 1919. In it, they justified their decision by claiming that they could not remain passive while the spreading of Bolshevism and the Romanian attack ${ }^{2}$ threatened their home country. They decided to flee for no other reason than to save Hungary and according to surviving documents, the fugitives were never captured. This case may be considered a curiosity as there were plenty of instances when prisoners of war escaped but it seems that none of them left such ideologically justified farewell letters. Today, the letter can be found in the Historical Archive of the Italian Army Staff in Rome. ${ }^{3}$ It was handwritten in German in pencil on the back of a table containing a list of prisoners of war, which was also in German. The document was filed with an accompanying letter numbered 623 Pers, dated 31 May 1919, written by Colonel de'Medici, Chief of Staff of the Hinterland Commissariat, along with an Italian translation of the farewell letter written in pen and submitted to the High Command's Office of Mobilisation and Organization. The accompanying letter states that the fugitives fled from Labour Corps no. 609. The entire batch of documents was forwarded on 7 June 1919 by Brigadier General Ago, Head of the High Command's Office of Mobilisation and Organization, with an accompanying letter to the secretary where the matter was probably closed.

According to a document dated 10 August 1918, the 609 ${ }^{\text {th }}$ Prisoner of War Labour Corps was subordinated to the Hinterland Commissariat. ${ }^{4}$ At the beginning of 1919 , the Labour Corps consisted of 353 Hungarian prisoners of war stationed and working in the town of Ghertele and gathering military materials under the direction of the Seven Towns Plateau and the Grappa County Recycling Office. According to a side-note, collecting military items was the only task the prisoners were given for the entire duration of their stay. ${ }^{5}$

1 For the collapse of Hungary after the First World War, see ORMOS, Mária. From Padua to the Trianon, 1918-1920. Budapest : Akadémiai, 1990; For Hungarian prisoners of war in Italy see: RESIDORI, Sonia. Nessuno è rimasto ozioso. Milano : FrancoAngeli, 2019; BAJA, Benedek - PILCH, Jenő - LUKINICH, Imre - ZILAHY, Lajos (eds.) Hadifogoly magyarok története. Vol. I - II. Budapest : Athenaeum, 1930.

2 Almost immediately after the signing of the Armistice of Belgrade, Romanian forces advanced on the territory of the Hungarian state, occupying territories up to the line of the river Tisza. The Romanian forces then joined the Entente forces attacking the Hungarian Republic of Councils, their advance halted only at the western border of Hungary. We do not know exactly what the fugitives meant by the "Romanian attack". They could have been referring to the occupation of Transylvania, but also the attack on the Republic of Councils.

3 Archivio Ufficio Storico dello Stato Maggiore dell'Esercito (AUSSME), Rome, Fond F-11, bundle No 129, File no. 5.

4 AUSSME, Rome, Fond F-11, bundle No 126, 1. Lieutenant Colonel Barbasetti to the Mobilisation and Organisation Office of the High Command. 10 August 1918, ser. n. 92532.

5 AUSSME, f. F-11, bundle No 126, 2. Situazione P[rigionieri di]. G[guerra]. comunque dipendenti Armate e G[randi]. U[nità]. divisi per nazionalità - località lavoro. $\mathrm{N}^{\circ}$ distintivo delle compagnie $\mathrm{L}$ [avoro]. $\mathrm{P}$ [rigioneri]. e Centurie. [1919]. Without any signature, serial number or date. 
Given that the number of POWs in labour corps generally declined over time, the statement above was probably made at the beginning of the year. By 1 May 1919, the labour corps consisted of only 258 Hungarian soldiers who collected military materials under the supervision of the Lusiana Route Commandership by order of the Breganze Recycling Office. ${ }^{6}$ The escape probably took place from this area. The Labour Corps was dissolved on 16 October 1919 at the site established in Val di Non. ${ }^{7}$

Unfortunately, it was not possible to find out which camps the prisoners had come from, at what date they had been captured or when they were able to return home after the Labour Corps was dissolved. There is no record of the commanders either, all we know is that he was apparently well-liked by the writers of the letter. On the other hand, the mandate of the Labour Corps is stated in a surviving document. On 11 November 1918, Luigi Meschinelli, president of the Vicenza County Department of Agriculture, requested 9000 POWs from the Ministry of War to be distributed as follows:

- 4000 prisoners to the Seven Towns Plateau, (Altopiano dei Sette Comuni)

- 1000 - 2000 to the western slope of Monte Grappa

- 1000 to Brenta Valley

- 500 to the Rio Freddo and Posina valleys

- 500 to the Tonezza Plateau

- 500 to the Astico Valley

- 500 to the Leogra Valley and Novegno

The prisoners of war were responsible for filling war trenches, collecting scrap metal and explosives and preparing the land for agricultural production. If all of these could not be carried out quickly enough, the applicant considered that the land should at least be brought to a condition suitable for grazing. The Ministry of War most likely provided only 4000 prisoners of war to work on the Seven Towns Plateau and on 8 January 1919, the department protested about the withdrawal of said workforce while urging for 9000 labourers in total to be allocated. ${ }^{8}$ Based on the description of activities performed by the $609^{\text {th }}$ Prisoner of War Labour Corps, the fugitives had also been involved in restoration work.

According to the farewell letter, the detainees refrained from escaping for a long time out of respect for their commander until the uncertainty of their repatriation made them convinced that it was time to act. Commanders were indeed punished for both successful and unsuccessful escapes. ${ }^{9}$ The process of returning home may have seemed truly unpredictable for the average prisoner of war. In April and May 1919, repatriation started ${ }^{10}$, but during the first period it only applied to those who were unfit for work:

6 AUSSME, f. F-11, bundle No 126, 2. Intendant Service: Specchio indicante i reparti lavorativi di guerra, Compagnie e Centurie L. P. comunque presenti nel territorio di propria giurisdizione alla data 1 Maggio 1919. Without any serial number.

7 AUSSME, f. F-11, bundle No 126, 2. Command of the territorial army corps of Verona: Elenco dei servizi e stabilimenti dipendenti nella seconda quindicina di ottobre 1919. Verona, 31 October 1919, serial number 8832R.S.M.

8 AUSSME, f. F-11, bundle No 128, 3. Luigi Meschinelli to the Ministry of War, 11 November 1918, serial number 612; AUSSME, f. F-11, 128, 3. Luigi Meschinelli to the Mobilisation and Organisation Office of the High Command. 8 January 1919, serial number 30.

9 See SZÖLLÖSY, Aladár. Szerb hadifogság. Szerbia, Albánia, Itália 1914-1918. Szöllösy Aladár naplója. [Budapest], 1925. pp. 89-90.

10 More specifically: it resumed, as the repatriation of persons unfit for work may be perceived as a continuation of the exchange of severely ill patients that began during the war. See also KEGLOVICH, Rita. Lo scambio dei prigionieri tra Italia e Ungheria durante e dopo la Prima guerra mondiale. In Rivista di Studi Ungheresi Nuova Serie, 2016, Vol. 30, No 15. pp. 88-100. 
- Invalids who needed no care at all

- Invalids and sick POWs who were able to be transported according to the general prescriptions of the exchange of the "grand blesses"

- Any sick or invalid POW whose affliction had lasted for at least two months ${ }^{11}$

- All invalid POWs in hospitals were to be sent home without additional medical control

- Persons held in prison camps but fulfilled the criteria of the exchange of "grand blesses" had to go to Calci first for an official medical examination. ${ }^{12}$

The following is an account of prisoners of war who died or were sent home due to their inability to work. The list is broken down by major administrative units and by nationality: ${ }^{13}$

Tab. 1. An account of prisoners of war who died or were sent home due to their inability to work.

\begin{tabular}{|l|c|c|c|c|c|c|}
\hline & \multicolumn{2}{c}{ Italian front } & \multicolumn{2}{c|}{ Albanian front } & \multicolumn{2}{c|}{ Macedonian front } \\
\hline & dead & taken home & dead & taken home & dead & taken home \\
\hline Austrians & 55 & 247 & 118 & 1 & - & - \\
\hline Hungarians & 25 & 1105 & 22 & - & - & - \\
\hline Polish & 1 & 44 & 4 & - & - & - \\
\hline Italians & - & 62 & - & - & - & - \\
\hline Ruthenians & 25 & 140 & 11 & - & - & - \\
\hline Yugoslavs & 33 & 813 & 12 & - & - & - \\
\hline Romanians & 3 & 18 & 1 & - & - & - \\
\hline Czechoslovaks & - & 83 & 9 & - & - & - \\
\hline Ukrainians & 3 & 5 & 5 & - & - & - \\
\hline Russians & - & 4 & - & - & - & - \\
\hline Bulgarians & - & - & - & - & 8 & 158 \\
\hline Total & 145 & 2521 & 182 & 1 & & 158 \\
\hline
\end{tabular}

As it may be seen, quite a number of sick Hungarian prisoners of war were able to return home at this time. Nevertheless, comparing the data in the account to the total number of prisoners shows that the amount repatriated at this time was rather insignificant. This fact is also shown by an account dated 1 May 1919 , according to which the number of prisoners in the war $z o n e^{14}$, and generally under control of the Italian authorities, were distributed by nationality as follows: ${ }^{15}$

11 AUSSME, f. F-11, bundle No 126, 5. POW Office to the High Command, 12 March 1919, serial number 5757.

12 AUSSME, f. F-11, bundle No 126, 5. Circular telegram of Caviglia. 13 March 1919, serial number 52222/9-A. On Calci see: GIOLI, Antonella (ed.) La Certosa di Calci nella Grande Guerra. Riuso e tutela tra Pisa e l'Italia. Florence : Edifir Edizioni Firenze, 2015.

13 AUSSME, f. F-11, bundle No 126, 5. Brigadier Ago to the Army Staff, 28 July 1919, serial number 92403; The chart lists "normal" prisoners of war, members of national legions were treated separately. It is important to clarify this detail since a significant number of Czechoslovak soldiers, volunteers among the Czechoslovak POWs, were sent home throughout the spring.

14 Following the Caporetto breakthrough, the war zone was extended to a significant part of Northern Italy and included, for example, the Messina Strait in addition to the Adriatic coast. The war zone also included an area in the Balkans controlled by Italian soldiers. PROCACCI, Giovanna. La società come una caserma. La svolta repressiva degli anni di guerra. In BIANCHI, Bruna (ed.) La violenza contro la popolazione civile durante la Grande guerra. Deportati, profughi, internati. Milano : Unicopli, 2006, p. 293.

15 AUSSME, f. F-11, bundle No 132, 1. Colonel Carletti to the POWs Office of the Army Staff, 11 May 1919, serial number 16120 . 
Tab. 2. An account dated 1 May 1919, according to which the number of prisoners in the war zone, and generally under control of the Italian authorities, were distributed by nationality as follows.

\begin{tabular}{|l|c|c|c|c|c|c|c|}
\hline & \multicolumn{3}{|c|}{ Italian Hinterland } & \multicolumn{3}{c|}{ War zone } & Total \\
\hline & $\begin{array}{c}\text { POW camps } \\
\text { and hospitals }\end{array}$ & $\begin{array}{c}\text { National } \\
\text { legions }\end{array}$ & Total & Italy & Balkan & Total \\
\hline Italians & 838 & - & 838 & - & 122 & 122 & 960 \\
\hline Austrians & 52750 & - & 52750 & 37996 & 7073 & 45069 & 97819 \\
\hline Hungarians & 50528 & - & 50528 & 27318 & 4026 & 31344 & 81872 \\
\hline Czechoslovaks & 3832 & 37617 & 41449 & - & 139 & 139 & 41588 \\
\hline Romanians & 5754 & 17873 & 23627 & - & 11 & 11 & 23638 \\
\hline Yugoslavs & 21440 & - & 21440 & 18972 & 946 & 1918 & 41358 \\
\hline Polish & 3889 & 8659 & 12558 & - & 400 & 400 & 12958 \\
\hline Ruthenians & 25123 & - & 25123 & 11337 & 2482 & 13819 & 38942 \\
\hline Others & 15255 & - & 15255 & 485 & 22 & 507 & 15762 \\
\hline Total & 179419 & 64149 & 243568 & 96108 & 15221 & 111329 & 354897 \\
\hline
\end{tabular}

It must be mentioned that the Italian authorities had difficulties creating the headings of nationality records on the basis of the successor states. The account above is fairly wellwritten, but in other copies we find separate categories for people of Carnian and Tyrolean nationality, also the Austrian-German rubric and so on. It is more important that by the time of the escape, the original number of nearly 350 thousand prisoners of war had been reduced by only about $0.85 \%$. This extremely insignificant repatriation rate caused an understandable sense of insecurity among the captives, which was exacerbated by news arriving from their home country given that the prisoners of war had access to newspapers and could learn about all important details published in the Italian and even foreign press. The officers were exempt from work so they had even more time to process the news. ${ }^{16}$ The aforementioned letter also attests to the fact that some privates took an interest in politics as well. It is interesting to note the way the escaped members of the homogeneous Hungarian labour force responded to the Romanian advance; they were not the only ones who had nationalist sentiments intensified as a result of their experiences during the war.

There are no surviving records that document all of the escapes, so no summaries of failed attempts were compiled either. However, we do know that the number of successful escapes soared in 1919 to an extent that caused concern among the Italian authorities, so much that they started to keep accounts. The list below contains data for prisoners of war who were fugitives for the six months before the end of June 1919:17

16 Some prisoners of war held on Asinara Island found time to document the history of the Hungarian Republic of Councils, mainly by translating Italian and French articles. KISS, Antal. Adalékok a magyarországi bolsevizmus történetéhez. Összegyüjtve az asinárai olasz hadifogságban, olasz és francia lapok híradásai nyomán. Budapest : Páros Print, 2009, pp. 23-176; The same officer also created excerpts of articles published in the journals Corriere della Sera; Giornale d'Italia; Il Messaggero; Oberrheinische Nachrichten; Le Petit Parisien; Il Tempo; Temps; La Tribuna.

17 AUSSME, f. F-11, bundle No 129, 5. Fugitive POW sor six months and still in hiding, 26 June 1919, serial number 91720 , forwarded by the telegraph of Pietro Badoglio of 22 July 1919, serial number 92314R.S. 
Tab. 3. Prisoners of war who were fugitives for the six months before the end of June 1919.

\begin{tabular}{|l|c|c|c|c|c|c|c|}
\hline $\begin{array}{c}\text { Italian Hinterland and War } \\
\text { Zone 26 }\end{array}$ June 1919 & Dalmatians & Austrians & Yugoslavs & Ruthenians & Hungarians & Ukrainians & $\begin{array}{c}\text { Czecho- } \\
\text { slovaks }\end{array}$ \\
\hline 1st Army & & 138 & 53 & 24 & 82 & & \\
\hline 3rd Army & 65 & 18 & 31 & & 6 & & \\
\hline 4th Army & & 24 & 17 & 42 & 13 & & \\
\hline 8th Army & & 27 & 8 & & 23 & 2 & \\
\hline Navy Command of Venice & & 23 & 31 & & & & \\
\hline Intendant Service & & 72 & 31 & 23 & 51 & & \\
\hline Air Force High Command & & & & & 1 & & 11 \\
\hline Engineer High Command & & 67 & 86 & 10 & 61 & 1 & 1 \\
\hline Albanian Army Command & & 4 & 4 & 1 & 1 & & 1 \\
\hline Eastern Expeditionary Corps & & & & & & & 13 \\
\hline Total & 65 & 373 & 261 & 100 & 238 & 13 & 13 \\
\hline
\end{tabular}

Tab. 3 Continued.

\begin{tabular}{|l|c|c|c|c|c|c|c|}
\hline $\begin{array}{l}\text { Italian Hinterland and War } \\
\text { Zone } 26^{\text {th }} \text { June 1919 }\end{array}$ & Polish & Serbs & Romanians & Bulgarians & Germans & Slovenes & Total \\
\hline 1st Army & & & & & & & 297 \\
\hline 3rd Army & & 2 & & & 10 & 132 \\
\hline 4th Army & & & & & & & 96 \\
\hline 8th Army & 3 & & & & & & 54 \\
\hline Navy Command of Venice & & & & & & & 181 \\
\hline Intendant Service & 3 & & 1 & & & & 1 \\
\hline Air Force High Command & & & & & & & 252 \\
\hline Engineer High Command & 4 & 1 & & & & & 16 \\
\hline Albanian Army Command & & 4 & 1 & & 204 & 1 & 205 \\
\hline Eastern Expeditionary Corps & & & & & & 1 \\
\hline Total & 10 & 7 & 2 & 204 & 11 & 1298 \\
\hline
\end{tabular}

When we organize the numbers above by countries existing between the two world wars, in descending order, the data looks as follows:

Tab. 4. Prisoners of war by countries existing between the two world wars, in descending order.

\begin{tabular}{|c|c|c|c|c|c|c|c|c|}
\hline Austrians & Yugoslavs & Hungarians & Bulgarians & Ukrainians & Czechoslovaks & Germans & Polish & Romanians \\
\hline 373 & 334 & 238 & 204 & 113 & 13 & 11 & 10 & 2 \\
\hline
\end{tabular}

Instead of concentrating them in labour corps, the Italian government typically placed Polish, Romanian and Czechoslovak prisoners of war in legions formed on the basis of nationality. Escape from these legions was indeed rather difficult, and in the case of these nationalities, it is understandable why the number of successful escapes was so low. There were few German prisoners of war in the Italian camps, but all other nationalities were represented in high numbers which means that escape was a common phenomenon in every group. In light of this, we can see it was not only the Hungarian prisoners of war who wanted to return home as soon as possible. Typically, escape was easier for prisoners who were assigned to labour corps and placed into less strictly guarded prison camps.

The necessity to step up and fight against Bolshevism also prompted some Hungarian officers to apply for permission to return home and be admitted into an expeditionary army 
with the sole purpose of suppressing the Hungarian Republic of Councils. For example, on 4 April 1919, Lieutenants Dr. Miklós Szemes and Dr. Viktor Kálnoky filed a petition with the Italian Ministry of War on behalf of the Hungarian POWs in San Benigno. The petition was answered ten days later: "Italy does not wish to interfere in Hungary's affairs. If we see the need for this in the future, we will utilize all necessary tools." ${ }^{18}$ Nine Hungarian prisoners of war held in Sandhill Park, England, also requested the establishment of an expeditionary army to crush the Hungarian Republic of Councils and even submitted a request for arms, ammunition and some financial support. They did not receive an answer, even though they had the opportunity to speak to a senior general of the British Army about their aspirations. ${ }^{19}$ These efforts also fell in line with the wishes of certain Hungarian political circles.

Hungarians had asked the Entente forces for military intervention even before the Hungarian Republic of Councils was established. For example, György Szmrecsányi, the former head of the County of Pozsony, (Bratislava), first asked for the help of the Entente to suppress the People's Republic led by Károlyi Mihály, and later to supress the Hungarian Republic of Councils. ${ }^{20}$ These petitions were repeatedly ignored by Italian authorities, particularly after Prime Minister Vittorio Emanuele Orlando requested the Italian press to emphasize the "nationalistic" reasons behind the events in Hungary. ${ }^{21}$ Orlando did not sympathize with Bolshevism at all. The Italian Ministry of Foreign Affairs believed, however, that the Hungarian Republic of Councils might inadvertently create an opportunity for Italy to gain Hungary as an ally after the formerly pro-French country was let down by France. This thinking seemed perfectly logical within the context of the Italian-French rivalry to fill the power and economic vacuum in Central Europe.

Of course, Italian foreign policy advisors also sought contact with opponents of the Hungarian Republic of Councils but their endeavours were too late. By May 1919, the leading figures had come under French influence ${ }^{22}$ and Italy had no choice but to seek cooperation with the Hungarian Republic of Councils.

Ironically, just like the Károlyi governments had done previously on several occasions, the Hungarian Republic of Councils also requested the release of Hungarian prisoners of war. ${ }^{23}$ As they were considered an important labour force, the Italian government could not be easily convinced to release the labourers involved in production, or at least in

18 “Italia non puo intrometterse [Sic!] nelle cose dell’Ungheria” Olaszország nem kíván beleavatkozni Magyarország belügyeibe. Magyar hadifogoly-tisztek akciója a kommün letörésére 1919. április 4-én, (Italy does not want to interfere in Hungary's internal affairs. Action on Hungarian prisoners of war on 4 April 1919 to break the commune). In Eger Gyöngyösi Újság, 4 February 1934, p. 2.

19 UDVARY, Jenő. Angol fogságban (Captivity in Britain). In Magyar Katonai Közlöny, 1921, Vol. 9, No. 7-8, p. 500.

20 MOSCA, Rodolfo (ed.) I Documenti Diplomatici Italiani Sesta Serie 1918-1922. Vol. I. Rome : Libreria dello Stato, 1956, No. 884, pp. 471-472; GRISPO, Renato (ed.) I Documenti Diplomatici Italiani Sesta Serie 1918-1922. Vol. III. Rome : Libreria dello Stato, 2007, No. 10, p. 9.

21 MOSCA Rodolfo (ed.) I Documenti Diplomatici Italiani Sesta Serie 1918-1922. Vol. II. Rome : Libreria dello Stato, 1980, No. 937, p. 701.

22 GRISPO 2007, No. 649, pp. 663-666.

23 Archivio Storico Diplomatico del Ministero degli Affari Esteri (ASDMAE), Rome, fond: CP, 7. Sonnino to Orlando and Diaz, Paris, 26 February 1919, serial number 480; Magyar Nemzeti Levéltár Országos Levéltár (Hungarian National Archives) (MNL OL), Budapest, fond K73, Hadifogoly osztály, bundle No 18/79. The Hungarian People’s Commissariat of Foreign Affairs to the Spanish Consul in Budapest, Budapest, 17 April 1919, serial number 2005; MNL OL, f. K73, bundle No 4/28, The Hungarian People's Commissariat of Foreign Affairs to Bíró Samu, president of the Alliance of the relatives of the POWs in Italy, Budapest, 20 May 1919, serial number 50188. 
the restoration of war damage. ${ }^{24}$ The Italian Prime Minister even opposed the establishment of a committee meant to examine the issue of repatriation at the Paris Peace Conference. ${ }^{25}$

The establishment of an anti-Bolshevik expeditionary army was also hindered by the fact that some prisoners of war actually supported the Hungarian Republic of Councils. This fact is supported, for example, in Jenő Udvary's memoirs. According to the writer, "the 'Hungarian' officers predominantly declared the area around Dob Street, [part of the Jewish quarter in Budapest] as their narrower homeland" ${ }^{26}$ That is, he essentially labeled these officers Jews. Udvary wrote his memoirs after returning home, in the Horthy era when the narrative of "Jews are to be blamed for the Republic of Councils" was already widespread. In this light, it is not clear whether Udvary was expressing his own beliefs or was influenced by the spirit of the times. In our case, however, his reasons for supporting the Hungarian Republic of Councils are only a matter of details, the bottom line is that some people agreed with the regime's objectives.

There was a plan, though, based on the return of Hungarian prisoners of war from Italy which came to be considered by the Italian authorities. Gyula Gömbös, the next prime minister of Hungary, who then operated under the aegis of the Hungarian Anti-Bolshevik Committee, (ABC), in Vienna, developed a plan at the end of March 1919 in which he:

- requested recognition of the Hungarian Anti-Bolshevik Committee by the Entente, as well as the authorization of its resettlement from Vienna to Darda.

- asked the Entente to allow a Hungarian committee to go to Italy and help organize and repatriate the prisoners of war.

- asked the Entente to provide money and military material to equip two divisions, six armored trains and a fleet of ground and air force vehicles.

- requested Italy to contribute to the arming of Hungarian prisoners of war and to support the anti-Bolshevik intervention with Italian troops and armored trains along the Graz-Fehring line.

One of the plan's many weaknesses was that Gömbös wanted mobilization to take place in Čakovec, Pécs and Sombor. As some of these towns were situated in the territory of Yugoslavia, the Italian authorities could not accept the proposal. In addition, Gömbös could offer nothing to compensate for the assistance; he had no decisive political influence, so any promise of an Italian-friendly foreign policy could be considered nothing more than an unsecured statement. Also, even after the robbery of the Hungarian Embassy in Vienna, the $\mathrm{ABC}$ could not amass enough money to equip an entire army. ${ }^{27}$ Therefore, it is not

24 In mid-October 1918, the Ministry of Agriculture even suggested that due to the chronic shortage of labour in undeveloped lands, the available prisoners of war would not be enough and they would have to ask the Allies to provide an additional 100 thousand prisoners. Archivio Centrale dello Stato (ACS), Rome, fond PCM Prima Guerra Mondiale, 100. Giovanni Battista Miliani to Vittorio Emanuele Orlando, Rome, 15 October 1918, serial number 9652; Orlando, however, immediately rejected the proposal for strategic reasons. ACS, f. PCM Prima Guerra Mondiale, bundle No 100. V. E. Orlando to G. B. Miliani, Rome, 21 October 1918, serial number 3228.

25 ACS, fond Carte Orlando, bundle No 79, 1618, 5. Orlando to Petrozziello, Paris, 24 May 1919 1:30, without any serial number.

26 UDVARY 1921, p. 500.

27 GÁBOR SÁNDORNÉ. Az 1919-es bécsi magyar ellenforradalmi emigrációról (On the Hungarian counter-revolutionary emigration in Vienna in 1919). In Párttörténeti Közlemények, 1964, Vol. 10, No. 3, pp. 114-155. 
surprising that after an exchange of letters in which France prohibited the organization of a powerful Hungarian army, the Italians decided to close the matter. ${ }^{28}$

In mid-July, István Bethlen, the head of the $\mathrm{ABC}$ and the next prime minister of Hungary, repeated his request for a counter-government envoy to visit prisoners of war in Italy as well as the repatriation of the prisoners. On 21 July 1919, Luigi Vannutelli Rey, an official at the Ministry of Foreign Affairs in Rome, jotted the following hand-written note on a document discussing Bethlen's application: "The Min[istry] would support this thing in principle, but the most appropriate [implementation] modalities still need to be specified." There is a second note underneath in someone else's handwriting, also in black pencil, which states: "Vannutelli [Rey] has no objection from a political point of view - [Arturo] Ricci-Busatti - no legal difficulty."29

The Italian authorities issued an authorization in which they gave consent to mass repatriation, although not necessarily to Gömbös's plan as well. It cannot be excluded with certainty, however, that the Italian authorities specifically intended to revive the plan for the expeditionary army on the basis of family memory. The Italians even asked Lieutenant Rezső Schamschula, the highest-ranking Hungarian POW in Italian hands, to accept command of a unit organized from prisoners of war. Schamschula refused, saying that he would not lead a war against his own country. ${ }^{30}$ The proposal could not have been made in April 1919, since at that time everyone on the Italian side opposed Gömbös's suggestion. Therefore, the most likely possibility is that the sudden reconsideration of the idea happened at the end of July of the same year.

This attempt for intervention, otherwise entirely unviable, can only be explained by the desperate efforts of Italian authorities to improve their relationship with the countergovernment of Szeged during the last days of the Hungarian Republic of Councils, when only the date but not the fall itself, was still uncertain. By that time, Italian influence in the Danube basin had diminished considerably after the Italian military mission in Czechoslovakia was terminated at the end of May 1919. Under these circumstances, it was important to keep Hungary in the Italian sphere of interest considering that Italy held positions only in Romania at this time. It is certain that this insignificant attempt failed to improve the relationship between the Szeged counter-government and the authorities in Rome. ${ }^{31}$ In addition, the Romanian army proved sufficient to overthrow the Hungarian Republic of Councils and by the end of August 1919, the mass repatriation of Hungarian prisoners of war began. ${ }^{32}$

28 ASDMAE, f. CP, bundle No 9, 18. Macchioro Vivalba to Sonnino, Vienna, 9 April 1919, arrived on 15 April, serial number 01436/422; ASDMAE, f. CP, bundle No 9, 18. De Martino to Macchioro Vivalba, Paris, 4 May 1919, serial number 01456.

29 ASDMAE, f. CP, bundle No 23, 3. Borghese to Vannutelli, 19 July 1919 14:10, arrived on 20 July 9:00, serial number 1498.

30 KAJON, Árpád - SUSLIK, Ádám. A Monarchia katonája. Schamschula Rezső tábornok élete (A soldier of the Monarchy. The life of Rezső Schamschula). Budapest : Magyar Napló, 2019, p. 337.

31 This culminated in open hostility by mid-August 1919. ASDMAE, f. CP, bundle No 7. Borghese to Vannutelli Rey, Vienna, 13 August 1919 20:30, arrived on 14 August 10:00, serial number 2586/1790.

32 MNL OL, f. K73, bundle No. 4/28. Takács-Tolvay to the POWs Office of the Hungarian Ministry of Foreign Affairs, Vienna, 19 September 1919, serial number 1534/hdf; By this time, repatriation of the "oppressed" nationalities had been largely completed but persons returning to the Kingdom of Serbia, Croatia and Slovenia were repatriated only after most of the Hungarian and the German-speaking prisoners had already gone home. TORTATO, Alessandro. La prigionia di guerra in Italia 1915-1919. Milano : Mursia, 2004, pp. 145-161. 
In an ironic twist of fate, an event took place on the way home that would have been almost unimaginable in the prison camp: the prisoners of war were "endangered" by left-wing ideas. Mimicking similar attempts by the Károlyi and Berinkey governments, the People’s Commissariat for Foreign Affairs of the Hungarian Republic of Councils wanted to send a Red Cross delegation to visit Hungarian prisoners of war in Italy but the Italian authorities never authorized any visits. ${ }^{33}$ The journey home of the prisoners, however, was led through Austria and here, according to the memoirs of a Hungarian officer who had received the first group of prisoners of war at Villach, Captain Milán Szekulits ${ }^{34}$ :

- The state and spirit of the returnees was good. They were enjoying a good order and trusted the officers. The prisoners of war manifested surprisingly good political judgment and the officer did not find any Bolshevist or communist elements in the first shipment, 44 persons.

- On the other hand, the Socialists and Communists employed strong propaganda among the Austrians. The Austrian headquarters in Villach opposed the matter but could not take effective action against the propaganda. In Hungary, Szekulits suggested that the returnees should be quarantined, citing a threat of contagion or lice infestation, and he also suggested submitting the former prisoners of war to counter-propaganda, which he thought should begin while they were still in Italy. ${ }^{35}$

The Austrian left-wing agitation was intended to prevent returnees from entering the National Army, but its effectiveness was greatly overestimated by some Hungarian soldiers. ${ }^{36}$ In light of past experience, the Hungarian authorities finally decided not to ask for permission to deploy a preventive Italian agitation committee and the Hungarian officers managed to curb the cross-border agitation on their own. The transfer took only about three hours, so the disturbance was not likely to cause significant damages. ${ }^{37}$

The Italian authorities dealt with repatriation in a rather improvisational way, proven among other ways by the fact that they only requested a map showing the new borders from the Italian Ministry of Foreign Affairs in mid-September, almost one month after the repatriation had been begun. ${ }^{38}$ This delay is inexplicable considering that until 20 March 1919, military authorities had requested in advance a list of those prisoners of war from Transylvania that wished to return to their homeland in spite of knowing that Transylvania was no longer under Hungarian rule. Therefore, it is undoubtable that the complex ethnic composition of the area and the shifting of borders was known to the Department of War prisoners of the Ministry of War. ${ }^{39}$ Nevertheless, the omission occurred and as a result in September 1919, the Hungarian authorities received some POWs whose homeland was

33 See also MNL OL, f. K73, bundle No 5/29. The Direction of the Red Cross to the Hungarian People's Commissariat of Foreign Affairs, Budapest, 3 May 1919, serial number 477.

34 Earlier he was also a POW in Forte Procolo (Verona), he returned to Hungary in 24 July 1919. ASDMAE, f. GPO 1915-1918, bundle No 381. Liutenant Colonel Giovanni Zanghieri to the Ministry of Foreign Affaires, 26 August 1919. serial number 39885.

35 MNL OL, f. K73, bundle No 14/55. Captain Milán Szekulits to Lieutenant Colonel István Pawlas, Warmbad-Villach, 14 August 1919, serial number 50870.

36 Colonel Kamilló Kárpáthy, head of the Ministry of War, Group I, wanted to raise the issue to the ceasefire Entente missions as well. MNL OL, f. K73, bundle No 14/55. Colonel Kamilló Kárpáthy to the Minister of Foreign Affairs, Budapest, 25 October 1919, serial number 17166/eln./.-1919.

37 MNL OL, f. K73, bundle No 14/55. Minister Haller to József Somsich, Budapest, 10 October 1919, serial number 35/Kat.eln; and the answer dated 17 October 1919.

38 ASDMAE, f. CP, 23, 3. Galli to Albricci, Paris, 28 September 1919, serial number 03433.

39 AUSSME, f. F-11, 126, 5. POW Office to the High Command, 12 March 1919, serial number 5757. 
on the other side of the new Trianon border. The relationship between the authorities and these returnees was rather ambivalent. After leaving Villach, the prisoners had to be transported to the camps of Zalaegerszeg and Csót, where they were divided into "reliable" and "unreliable" groups. The "reliable" prisoners from Szeged, Transdanubia and the Slovak highland - still unoccupied at that time - were classified as "ready to be drafted" after two months of rest. Persons from occupied territories, on the other hand, could only be enrolled on a voluntary basis. The "unreliable" ones from Szeged, Transdanubia and "the unoccupied Slovak highland" were retained in the camps of Zalaegerszeg and Csót, while the National Army handed over returnees from the rest of the country to the occupying army. ${ }^{40}$

Of course, there were some prisoners of war who stayed in Italy but only a handful of such cases are known. The decision to remain was usually due to a lack of relatives in Hungary ${ }^{41}$ or starting a family in Italy. ${ }^{42}$ One exceptional case among the prisoners remaining in Italy after World War I is that of former Lieutenant in the Marines Gergely Markó, who became a monk. ${ }^{43}$

The fate of the former POWs who stayed in Italy is unknown at this point, but it is likely that they fared well in their new country. Italian military authorities stipulated that only those prisoners of war whose good military behavior was certified by the military authorities could remain in Italy and any person permitted to stay had to prove within a month that they were living on their own income, otherwise they were expelled immediately. In addition, the Ministry of Foreign Affairs requested a certificate from their original residence stating that the applicants had a clean criminal record prior to the war. ${ }^{44}$ The Department of War Prisoners of the Ministry of War published an even stricter order on 3 January 1920 stating that cases pending would continue to be processed according to the previous selection criteria, but no further applications for stay would be accepted. The reason for this decision was that due to the mass discharge of Italian soldiers, even employment of the domestic workforce became difficult and the authorities did not want the release of the prisoners to turn into a competition. At the same time, deserters and all internees who could not return home for legitimate reasons continued to be permitted to emigrate to a third country. ${ }^{45}$

40 MNL OL, f. K73, bundle No 4/28. Miklós Horthy to József Takács-Tolvay, Siófok, 6 September 1919, serial number 1112/III.a.

41 See the case of Béla Román, a Hungarian born in Budapest, who was a prisoner of war in Bitonto. Both his parents had died and he had no other relatives so he opted to acquire Italian citizenship and stay in Italy. ACS, f. Min. Int. Dir. Gen. PS, Profughi e internati di guerra, 1311, Román Béla. POWs Office signed by General Giuseppe Malladra to the Internal Security High Directorate of the Ministry of Internal Affairs, Rome, 3 May 1919, serial number 12290.

42 See the case of Polish private Michele Kopeling, who fell in love with a local girl during his captivity in Calabria, married her and did not return home. AIELLO, Giovanni. Prigionieri austro-ungarici in Calabria. In LEONCINI, Francesco (ed.) Il patto di Roma e la legione Ceco-Slovacca. Vittorio Veneto : Kellermann, 2014, p. 170; It is an interesting detail that this latter possibility had already been considered before; see Giovanni Verga's novel Sulle lagune, published in the magazine La Nuova Europa in Florence during 1862-1863, which tells the love story of Hungarian officer Stefano de Keller and Giulia, a girl from Venice, while also depicting the Austrian oppression in Veneto and Mazzinian ideals. MADARÁSZ, Imre. Risorgimento italoungherese nel romanzo di Giovanni Verga "Sulle lagune". In NEMETH PAPO, Gizella - PAPO, Adriano (eds.) Unità italiana e mondo adriatico-danubiano. Trieste : Luglio Editore, 2012, pp. 59-64.

43 Hadtörténelmi Levéltár, Budapest, fond I. vh, bundle No 4361. Veterinarian Lieutenant József Kukuljevič: Report on his captivity in Serbian and Italian hands.

44 AUSSME, f. F-11, bundle No 132, 1. Circular letter of Minister of War Albricci, Rome, 10 September 1919, serial number 41888 .

45 AUSSME, f. F-11, bundle No 132, 1. Circular letter of Minister of War Albricci. Rome, 3 January 1920, serial number 1077 . 
It can therefore be seen that some Hungarian prisoners of war who had access to fairly up-to-date information on the changes in Hungary sympathized with the Hungarian Republic of Councils, while others wished to fight against it. Based on escape statistics, there is no doubt that this and similar political or "nationalism" reasons had little effect on the desire of the prisoners of war to leave. In 1919, everyone who was able wanted to go home, and many were not afraid to attempt to flee if they saw no other opportunity.

Several Hungarian administrations also attempted to exploit the case of the prisoners of war for their own purposes, but the interests of the great powers did not allow this intention to materialize. Thus, other than a few exceptional cases, the mass repatriation of Hungarian prisoners of war was not possible until August 1919, and at this time they were faced with the desire for control by the domestic authorities. The post-war transition to peaceful civilian life of soldiers captured on the Italian front was thus considerably delayed, and due to the many conflicting interests, they were only able to return to their former lives and occupations in 1920.

\section{Cite:}

JUHÁSZ, Balázs. Hungarian POWs in Italy and Their Future Prospects After WWI. In Forum Historiae, 2021, Vol. 15, No. 1, pp. 64-75. ISSN 1337-6861. DOI: https://doi.org/10.31577/forhist.2021.15.1.6

Balázs Juhász

Eötvös Loránd Tudományegyetem Bölcsészettudományi Kara

Új és Jelenkori Egyetemes Történeti Tanszék

Múzeum krt. 6-8, 1088 Budapest, Hungary

email: juhasz.balazs@btk.elte.hu 